Managing Guarantee Programs in Support of Infrastructure Investment

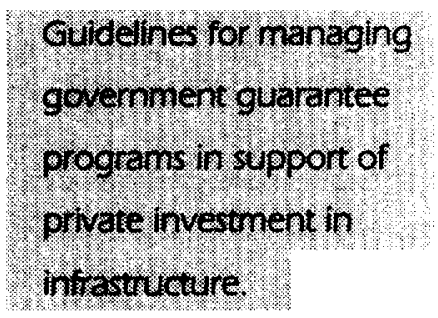

Michael Klein

The World Bank

Private Sector Development Department 
Policy Researci Working Paper 1812

\section{Summary findings}

Klein discusses the risks of infrastructure projects and the costs of capital, rationales for government support of private infrastructure ventures, and approaches to managing government guarantees of private infirastructure investments. Among his recommendations:

- The decision to grant a guarantee for debts associated with infrastructure projects should be based on an explicit cost-benefit analysis for the project to be guaranteed, including an assessment of the likely cost to taxpayers and the impact of alternative forms of government support.

- In principle, when the rationale for government support arises from the difference between effective willingness to pay and social benefits, the support should take the form of subsidies supplementing the price customers are willing to pay for a service. Such subsidies are contingent on the effective provision of the subsidized service. They allow the private provider to be guided by the full benefits of the project without reducing the incentives to perform (as would occur with risk sharing through cofinancing or guarantee).

- Guarantees of policy risks should support a credible reform program but not substitute for it. In the medium term, policy reform should obviate the need for a guarantee. Beneficiaries of guarantees should bear a part of the risk, as with a deductible. In structuring guarantees, governments need to take care that performance incentives for private investors are not undermined. Essentially, this means not covering normal business risk, including exchange rate and interest rate movements.

- Governments should consider sharing normal business risks only as a last resort, if at all. To prevent excessive government exposure, decisions should be transparent and based on explicit cost-benefit analysis. Monetary limits should be placed on total government exposure, and there should be an exit strategy for the government wherever possible.

- Governments should consider creating a central office charged with managing guarantee exposure, to limit taxpayer exposure and to strengthen private performance incentives.

- Governments should establish a system to update the valuation of its guarantee exposure periodically as well as mechanisms to adjust guarantees or to seize collateral when fees are not paid. The use to which guarantees can be put should be clearly limited, and policies for appropriate guarantee fees and coinsurance requirements should be established.

This paper - a product of the Private Sector Development Department - is part of a larger effort in the department to analyze issues arising from private participation in infrastructure. Copies of the paper are available free from the World Bank, 1818 H Street NW, Washington, DC 20433. Please contact Sandra Vivas, room G4-031, telephone 202-458-2809, fax 202-522-3481, Internet address svivas@worldbank.org. August 1997. (25 pages)

The Policy Research Working Paper Series disseminates the findings of work in progress to encourage the exchange of ideas about development issues. An objective of the series is to get the findings out quickly, even if the presentations are less than fully polished. The papers carry the names of the authors and should be cited accordingly. The findings, interpretations, and conclusions expressed in this paper are entirely those of the authors. They do not necessarily represent the view of the World Bank, its Executive Directors, or the countries they represent. 


\title{
Managing Guarantee Programs in Support of Infrastructure Investment
}

\author{
Michael Klein
}



Managing Guarantee Programs in Support of Infrastructure Investment

\author{
Table of Contents
}

Page No.

I. Risks of Infrastructure Projects and the Cost of Capital ......................... 1

Project Risks ..................................................................................................... 1

The Cost of Capital......................................................................................... 2

Guarantees: Their Role, Benefits and Costs ......................................................... 4

II. Rationales for Government Support of Private Infrastructure Ventures . 6

Government Support for Projects....................................................................... 6

Basic Rationales for Government Support........................................................ $\quad 8$

Key Trade-Offs in Assessing Costs and Benefits of Government Support ..... 17

Incentive Issues...................................................................................... 17

III. Managing Guarantees................................................................................... 19

Allocating Responsibility for Guarantee Decisions......................................... 19

Valuation of Government Support Including Guarantees ............................. 20

Managing Risk.......................................................................................... 22 



\section{Risks of Infrastructure Projects and the Cost of Capital}

\section{Project Risks}

1. Normal Business Risks. Investors in infrastructure projects, for example, power plants, gas pipelines, tollroads or water systems are subject to a number of business risks, like any other investors. Key categories of risk are:

- commercial risk: construction delays and overruns, increases in operations and maintenance expenses, changes in prices of inputs and outputs, availability and quality of the supply, contractor insolvency, etc. and

- financial risk: financial market interruption, interest rate and exchange rate fluctuations.

2. Policy Risks. Infrastructure projects tend to have lengthy construction periods and are generally long-lived, often spanning several decades. During this long time period, investors have to entrust their fortunes to the host community, because they generally do not have the option to take their investment away if the business environment becomes intolerable. Investors are thus very vulnerable to some form of (creeping) expropriation or non-performance of contractual parties, for example, uncreditworthy or unreliable government entities, parastatal breach of contract, change of law and trade regimes, revocation of permits, expropriation, war, sabotage, etc.

3. Furthermore, revenues from infrastructure ventures are often denominated in local currency. To the extent that foreign investors are involved, they then face the risk of currency convertibility and transfer. Typically, investors ask for government guarantees against these key risks or other related types of risk that may be called political or policy risks, because the risks are under the control of government or involve undertakings of a government entity.

4. Risk Allocation Process. Although simple enough to prescribe in general terms, the actual risk allocation process through a project's regulatory, contractual and financial framework represents a very detailed and complex exercise. Factors influencing this process will include: (i) development status of the enabling legal and regulatory environment, as well as local financial markets; (ii) market structure (natural monopoly vs. multiple potential providers); (iii) macroeconomic conditions; (iv) financial, technical and institutional capabilities of the host government and relevant SOEs; (v) availability and quality of information required to conduct due 
diligence undertakings; (vi) tendering process utilized (structured vs. unstructured competitive vs. direct assignment); and (vii) risk profile of the sector and project in question.

\section{The Cost of Capital}

5. The Cost of Capital in Countries with Sound Policies. While infrastructure projects are thus subject to a number of special or severe risks, they do not require government guarantees in jurisdictions with a well-developed policy framework. On the contrary, investors are willing to invest at low cost of capital in countries with macro-economic stability and a regulatory regime, which:

- credibly allows investors to operate on a commercial basis, including a clear path to recourse when policy problems occur; and

- yields good infrastructure services at prices which are acceptable to consumers and politicians.

In such countries (for example, the United States, Germany and Hong Kong) attracting investment is comparatively easy. Indeed, it may be a choice investment for conservative long-term investors such as pension funds or insurance companies.

6. Infrastructure utilities operating under a well established system of price regulation, where price is based on cost (variants of rate-of-return regulation), tend to fund themselves at rates of return somewhere between the real risk-free rate (treasury bill rate) of 3 to 4 per cent and the average real return on equity of some 6 to 8 per cent (see Blanchard, 1993). In stable economies with more competitive solutions for infrastructure industries (telecommunications, some electricity systems) or with price regulation which may be less cost-based (for example, price-cap regulation), the cost of capital may be similar to that of the average real return on equity of 6 to 8 per cent (see Alexander, 1995). ${ }^{1} \quad$ The weighted cost of capital thus tends to range from 5 to 8 per cent in real terms.

7. Of course, these numbers should be considered indicative only for the orders of magnitude of the cost of capital in stable economies with credible sectoral policies in place. They are about the best one can hope for. The basic message is that the cost of capital for private infrastructure schemes does not have to be high and may well be lower than required rates of return in other sectors that are more subject to competitive forces. It should also be clearly understood that exposure to competitive forces, particularly market risk will tend to raise the risk premium of investors and, therefore, the cost of capital. Real competition will, however, tend to lead to better service, lower cost and overall better economic performance outweighing the higher cost of capital for an individual firm.

8. Corporate Finance. Most investment in private infrastructure in countries with wellestablished regulatory policies is funded out of internal cash generation - notwithstanding the recent popularity of so called "project finance". For example, investor-owned utilities in the United States fund over 70 per cent of their new investment our of retained earnings - and often much more. New

1 Competition increases uncertainty and therefore the cost of capital. However, effective competition tends to lower other costs by more than the cost of capital increases. 
share issues or debt play a minor role - as is also the case in most investments in manufacturing companies. To the extent that debt financing is used in these cases, it is in the form of corporate finance, that is, lenders look for repayment to the assets and the cashflow of the whole corporation which sponsors the project. Interest rate spreads on corporate debt of an investment grade company may be in the order of 15 to 225 basis points above treasuries, depending on the sector and the exact rating.

9. Project Finance. However, in a number of cases, sponsors are undertaking projects that are so large relative to their own financial size that they wish to insulate themselves from downside risks and/or for which they could simply not raise enough debt on the strength of their corporate balance sheet, for example, because they have too many projects. They may then try to use project finance techniques, that is, incorporate the project as a separate, special purpose company and seek investors who only look to the project company for repayment, not to the sponsor. Such project finance deals have been frequent for U.S. independent power projects, ${ }^{2}$ and mega-projects such as Euro-tunnel and Euro-Disney. For these projects, it has been possible to design so-called security packages ${ }^{3}$ for lenders without government guarantees and with minimal undertakings, which still allow the debt to be of investment grade (BBB or above). Euro-Disney was able to issue 100-year bonds. Interest spreads on investment grade project debt may start at around 70 basis points for completed projects, and 175 basis points for projects under construction, and can reach over 300 basis points.

10. The Cost of Capital in Countries with High Policy Risk. However, in many less stable economies with high country risk and unproven regulatory regimes, investors in infrastructure projects are often asking for real returns on equity in the order of 20 per cent or more and for real returns on debt which may exceed the risk-free rate by some 3 to 5 per cent for a total real return of at least 6 to 9 per cent, if not more. For a project with a 70 per cent debt component - an illustrative assumption - the average cost of capital would thus be at least 12 to 13 per cent - about double that in stable economies with well-established regulatory regimes and may often reach 20 percent. Many countries are so risky that investors are simply not willing to come.

11. To make the discussion of issues here less abstract, we proceed by looking at guarantee programs for a mythical country "Ruritania". Ruritania's country risk is similar to that of Mexico, Turkey or Argentina but below Colombia and Indonesia and above the Philippines and Pakistan. While Ruritania has not issued bonds in international markets during the last two years, this risk rating suggests that its credit might be rated below investment grade by credit rating agencies if a rating were sought. Assuming that Ruritania were rated similar to Mexico or Argentina, that is, BB or BB-, the spread on foreign dollar-borrowing over US-treasuries of equivalent maturity may be in the order of 300 to 500 basis points for sovereign borrowing and from 350 to well above 500 basis points for project debt, where projects benefit from certain guarantees such as performance guarantees for public entities and currency transfer risk. Equity investors claim they are seeking real rates of return above 20 per cent for a country like Ruritania.

2 For an analysis of risks in independent power contracts see E. Kahn (1991)

3 For a handbook of project finance techniques see F. Fabozzi and P. Nevitt, Project Financing (6th edition), Euromoney Books, 1997. 


\section{Guarantees: Their Role, Benefits and Costs}

12. The Need for Government Guarantees. It would appear unlikely that Ruritania could raise significant amounts of medium-or long-term debt for infrastructure projects without some government guarantees. ${ }^{4}$ Countries that have recently raised project debt without or with very limited government guarantees tend to be of investment grade rating, for example, Indonesia with the Paiton power project, and Colombia with the Centragas and Transgas gas pipeline projects. Colombia is the only country where in recent years investors in energy projects have gradually dropped requirements for guarantees of the performance of government purchasers. In the Philippines, the developing country with most (over 30 ) new private power projects, investors are still asking for government guarantees of power purchase agreements entered into by government utilities. The Philippines has, however, obtained progressively lower power prices from investors.

13. The Primacy of Risk Reduction. The more the government clarifies sector policy, withdraws from a sector and allows prices to be set at levels that cover investors' costs (including the cost of capital), the less it will need to provide performance guarantees or other types of sector policy guarantees. Argentina is a case in point where complete privatization of the power sector under an advanced policy framework has attracted private investors without the need for government guarantees. The policy, including privatization, was put in place over a two year period. The basic lesson is that the most effective way to attract investors is not to cover risks with guarantees, but rather to reduce risks. However, Argentina does continue to suffer from country risk perceptions (as opposed to sector policy risks), which complicate the attraction of funds for new investment. Only sustained macro-economic stability will bring the desired investment grade rating which is essential to tap the large savings of institutional investors at attractive prices. ${ }^{5}$

14. Costs and Benefits of Guarantees. Where the cost of capital is very high or finance difficult to attract at all, guarantees may help stimulate capital flows at reasonable rates. However,

\footnotetext{
4 At the moment there is no relevant infrastructure project experience in Ruritania. Potential investors are quite concerned about breach of contract by government entities. Despite Ruritania's liberal policy on repatriation of capital, long-term investors are also concerned about currency convertibility and transfer risk. Investors have purchased such insurance from the World Bank's political risk insurance arm, MIGA. Private insurers such as AIG have written policies for very small amounts covering expropriation risk, wrongful calling of bonds and convertibility risk for trade credits in agriculture and the manufacturing sector.

5 Within this context it is also important to note that the worldwide market for investment grade debt (i.e., those securities having a credit rating of BBB- or above as determined by the international rating agencies) is estimated on the order of $\$ 15$ to 20 trillion. However, many of these institutional investors (pension funds, insurance companies, mutual funds, endowments) face internal, industry and governmental restrictions which limit how much they can invest in subinvestment grade securities to less than 3 to $5 \%$ of their portfolios - of which only $1 \%$ is allocated to debt instruments. This $1 \%$ is then spread across three asset classes: corporate bonds traded in the Euromarket, local currency sovereign debt, and Brady bonds. In 1994, for example, institutional investors held only $\$ 126$ billion of emerging market debt. Moreover, given that project financings entail all risks associated with a sovereign and corporate issuance (political and macroeconomic instability, foreign exchange), as well as additional commercial risks (construction, operation and maintenance, force majeure) all-in funding costs for these securities should be in excess of those offered for sovereign issuances of similar size and maturity. This is often referred to as the "sovereign ceiling affect". Only special guarantees from parties with higher credit rating than the sovereign (e.g., the World Bank) could allow project debt to break through the sovereign ceiling.
} 
the provision of guarantees may reduce government's overall ability to borrow and entails direct costs in case a guarantee is called. One can estimate the fiscal impact of guarantees. In practice, such estimates tend to be broad approximations due to lack of all the necessary information to calculate exact equivalents. Nevertheless, the estimated cost of support can then be considered in a cost-benefit analysis of the project. The question is whether the undeniable benefits of guarantees are worth their cost and whether they are the most efficient instrument of government support.

Recommendation (1): The decision to grant a guarantee should be based on an explicit cost-benefit analysis for the project to be guaranteed, including an assessment of the likely cost to taxpayers and the impact of alternative forms of government support. 


\section{Rationales for Government Support of Private Infrastructure Ventures}

\section{Government Support for Projects}

1. Types of Support. Whenever projects require Government support to attract private investors, there are several ways to provide such support. It may take the form of a guarantee or a cash subsidy. Alternatively, the Government can invest debt or equity alongside the private investors. Finally, the government may provide complementary investments, for example, a feeder road leading to a private port project. The following discussion compares three types of government support: guarantees, cash subsidies and financial investment (debt or equity). The case of complementary investments or undertakings may be thought of simply as an in-kind subsidy, such that the arguments about cash subsidies apply.

2. In practice, private debt and/or equity investors may ask for a mix of government support encompassing some or all of the types of support mentioned above. For example, a private investors in a tollroad may ask the government to provide: i) a guarantee to maintain agreed tariff policy as well as currency convertibility; ii) a guarantee of refinance to lengthen credit maturity; and iii) subordinated debt to reduce the need for senior debt, while maintaining the profitability of equity. Arguments are often made that the project provides special social benefits justifying the support and that investors need protection against capricious policy changes. Often there are good reasons to provide support and private finance may not be forthcoming in sufficient amounts without it. However, to assess, which type of support is most appropriate from the government's (and society's) point of view, it is necessary to explore the possible rationales for government assistance.

3. Analysis of Differing Forms of Project Support. Any assessment of the appropriateness of government support involves the following steps. First, the rationale for government support should be established. Second, the possible appropriate instrument of support needs to be determined. Third, the incentive effects of each support measure - how it affects demand and costs - should be assessed. Finally, for each of these instruments the net present cost to government can be calculated and compared to likely benefits. Then the decision about the form and terms of government support may be made. 
4. A Hypothetical Example. The following discussion is based on a sample "project", which might be a tollroad, a power plant or a water distribution system. In the discussion it will be assumed that we are dealing with a tollroad. Table 1 lays out the "base case". To make the example relatively easy to follow some simplifying assumptions are made, which do, however, not change the basic arguments:

- all calculations are in real terms, that is, inflation is not considered;

- there are no taxes;

- there is no net depreciation, that is, maintenance contained in current costs restores the value of assets in each period of the project and the project lasts forever. Initial investment is thus equal to total assets in all later periods;

- net debt service paid in each period encompasses only interest and that principal is continuously rolled over;

- under these assumptions the annual return to (debt or equity) investors ( $R$ ) divided by the amount of original investment (I) is equal to the internal rate of return for the investor $(r)$ :

$$
\frac{\mathrm{R}}{\mathrm{I}}=\mathrm{r}
$$

- a key identity used in the calculations is:

Return on total assets (ROA) equals return on equity (ROE) times share of equity (e) in total assets plus return on debt (ROD) times share of debt in total assets (d):

$$
\mathrm{ROA}=\mathrm{ROE}^{*} \mathrm{e}+\mathrm{ROD}^{*} \mathrm{~d}
$$

This is the standard formula for the calculation of the weighted average cost of capital of a project or a firm; and

- the original investment is assumed to be 100 (units whatever relevant currency).

5. In this tollroad example, it is assumed that the project is fully financible from private sources with a debt - equity (or gearing) ratio (d:e) of 75:25 and a return on assets of 10.5 per cent. This translates into an interest rate of 8 per cent for providers of debt, expected with certainty. Equity investors would obtain a rate of return of 18 per cent at this gearing ratio. To simplify the exposition, it is assumed that the rates of return for debt and equity investors are equal to the required rates and that capital structure (i.e. the gearing ratio) does affect the cost of capital (i.e. the

6 This is a typical gearing ratio for many project financings. 
required return on assets of 10.5 per cent). This will not be so in reality, where a change in gearing will affect the riskiness of debt and equity and may not change the weighted average cost of capital by much. In the discussion, it will be pointed out how this assumption affects the nature of results.

TABLE 1: Base Case

\begin{tabular}{|l|c|c|c|}
\hline & $\begin{array}{c}\text { Possible Outcome } \\
\text { (Probability }=0.5)\end{array}$ & $\begin{array}{c}\text { Possible Outcome } \\
\text { (Probability=0.5) }\end{array}$ & $\begin{array}{c}\text { Expected } \\
\text { Outcome }\end{array}$ \\
\hline Price & 4 & 4 & 4 \\
Quantity & 5 & 2.5 & 3.75 \\
Revenue & 20 & 10 & 15 \\
Current Costs & 5 & 5 & 5 \\
Cash Flow & 15 & 5 & 10 \\
Return on Assets (100) & $15 \%$ & $5 \%$ & $10 \%$ \\
Private Debt Service & 6 & 5 & 5.5 \\
Private Equity remuneration & 9 & - & 4.5 \\
Share of Private Debt & & & $75 \%$ \\
Share of Private Equity & $75 \%$ & $75 \%$ & $25 \%$ \\
Share of Government Subordinated Debt & $25 \%$ & $25 \%$ & - \\
Share of Government Equity & - & - & - \\
Return on Private Debt & - & - & $7.3 \%$ \\
Return on Private Equity & $8 \%$ & $6.7 \%$ & $18 \%$ \\
Return on Government Subordinated & $36 \%$ & 0 & - \\
Debt & - & - & - \\
Return on Government Equity & - & - & \\
\hline
\end{tabular}

6. In the "base case" it is assumed that the tollroad charges a toll of 4 per vehicle. Demand (usage of the road) is uncertain and may amount to 5 vehicles per period or to 2.5 (e.g. two cars and a motorbike) per period with equal probability of 0.5 each. Current costs are assumed to amount to 5 yielding potential cashflows of 15 or 5 and an expected (probability weighted) cashflow of 10 . The cost of the road is 100 and it is to be financed with 75 per cent debt and 25 per cent equity. As can be seen from table 1 equity investors can expect a return of 18 per cent, whereas debt investors face an expected return of 7.3 per cent, below the required rate of 8 per cent. Without some form of government support the project will not be financible as planned.

\section{Basic Rationales for Government Support}

7. In the following, variations of the base case will be used to illustrate the major arguments about government support. We start with a review of the basic rationales for support. In principle, there can be three basic reasons for providing government support to private projects:

- the social benefits of the project may exceed private benefits (or effective private willingness to pay); 
- investors may require protection against political risks, which the government controls; and

- the government may take the view that risk premia required by private investors are higher than those required by government itself, that is, by the taxpayers.

8. Case I: Social Benefits Exceed Private Benefits. Consider now the cases where social benefits exceed private benefits. There are several sub-cases. First, private willingness-to-pay may be less than social benefits due to a type of benefit generated by the project, which does not accrue to the consumers, who can be charged. For example, if the introduction of safe drinking water reduces the danger of infection to people, who are not customers of the water system, it may be worth subsidizing a water project. Second, a project may benefit consumers whom the government wants to subsidize for reasons of equity. Third, in the case of natural monopolies, where variable cost of a service is lower than average cost, optimal utilization of the service may require a subsidy. For example, in the case of an uncongested toll road, the variable cost of using the road is minimal and consequently the toll should be low, so that the road is fully used. However, the total cost of the road cannot be recovered from such low tolls. Ideally, road users would be charged an access fee for the road, which covers the fixed costs. But this may not be feasible and a subsidy could be considered instead.

9. Table 2 illustrates a case where private willingness-to-pay is 2 , but a price of 3.1 is required to render the road financible. In this case, we disregard uncertainty and focus only on the difference between private and social benefits. Assuming that social benefits exceed 3.1 the project should be undertaken, but drivers are only willing to pay a toll of 2 . To attract private finance, the government may then provide a subsidy of 1.1 per vehicle passing the road. Alternatively, it could let the tollroad operator charge a toll of 2 and provide a subsidy for construction of 37.5, which could also be declared "subordinated equity" with some rights to returns should the project unexpectedly yield greater benefits, although this would change the character of normal equity and transform it into subordinated debt.

10. The opportunity cost of the upfront subsidy of 37.5 is equal to an annual payment of 5.5 if the government could alternatively invest 25 as equity with an expected return of 18 per cent and 12.5 as debt with an expected return of 8 per cent. 5.5 is also the annual payment needed to pay a subsidy of 1.1 per vehicle. Therefore, as long as the opportunity cost of government investment is evaluated at rates equal to returns required by private investors there is no difference in the net present cost of the two forms of subsidy.

11. However, the exposure to risk differs in the two cases. In the first case the government is not exposed to construction, operating and traffic risk. If the road is not built within cost estimates or not operated well or does not attract traffic the government does not pay. In the second case it will definitively pay. When the costs are considered equal we obtain: 
TABLE 2: Social Benefits Exceed Private Benefits

\begin{tabular}{|l|c|c|}
\hline & Social Benefit & Private Benefits \\
\hline Price & 3.1 & 2 \\
Quantity & 5 & 5 \\
Revenue & 15.5 & 10 \\
Current Costs & 5 & 5 \\
Cash Flow & 10.5 & 5 \\
& & \\
Debt Service & 6 & 5.0 \\
Equity remuneration & 4.5 & - \\
Share of Private Debt & $75 \%$ & $62.5 \%$ \\
Share of Private Equity & $25 \%$ & \\
Share of Government & - & - \\
Subordinated Debt & & 37.5 \\
Share of Government Equity & - & $8 \%$ \\
Return on Private Debt & $8 \%$ & - \\
Return on Private Equity & $18 \%$ & - \\
Return on Government & - & 0 \\
\hline $\begin{array}{l}\text { Subordinated Debt } \\
\text { Return on Government Equity }\end{array}$ & - & \\
\hline
\end{tabular}

Recommendation (2): In principle, when the rationale for government support arises from the difference between effective private willingness to pay and social benefits it should take the form of subsidies supplementing the price customers are willing to pay for a service. Such subsidies are contingent on the effective provision of the subsidized service. They allow the private provider to be guided by the full benefits of the project without lowering incentives to perform as would be the case under some form of risk-sharing via co-financing or guarantee.

12. Case II: Policy Risk. The second major reason for government support is that only the government is be able to cover some risks, such as currency transfer and breach of contract by government entities, for example, parastatals or municipalities. In this case the government could, of course, reduce risks by introducing appropriate reforms. Table 3 illustrates this case, which presumes that there is a risk that the public toll road authority that supervises the private tollroad concession may not honor its commitment to allow tolls to be set at 3.1. (Here it is assumed that drivers are willing to pay 3.1.) Instead, investors fear that under political pressure tolls may be dropped to 2 . The central government can then provide a guarantee that this will not happen. In the "pure" case when the central government has effective control over the tollroad authority it can ensure that the tolls will not be dropped and issue the guarantee confident that it will never be called. The existence of the guarantee then renders the tollroad concession credible at zero cost to the government. A price of 3.1 remains sufficient to provide investors with their required returns. This is simply the case of a country where contracts and rules are respected. 
TABLE 3: Pure Case of Policy Guarantee with Zero Social Cost

\begin{tabular}{|c|c|c|c|}
\hline 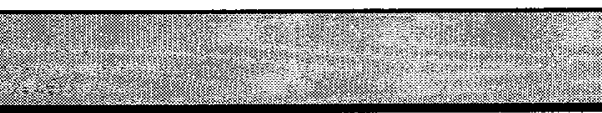 & $\begin{array}{l}\text { Possible Outcome } \\
(\text { Probability }=1)\end{array}$ & $\begin{array}{l}\text { Possible Outcome } \\
(\text { Probabilty }=0)\end{array}$ & $\begin{array}{l}\text { Expected } \\
\text { Oitroome }\end{array}$ \\
\hline Price & 3.1 & 2 & 3.1 \\
\hline Quantity & 5 & 5 & 5 \\
\hline Revenue & 15.5 & 10 & 15.5 \\
\hline Current Costs & 5 & 5 & 5 \\
\hline Cash Flow & 10.5 & 5 & 10.5 \\
\hline Debt Service & 6 & 6 & 6 \\
\hline Equity Remuneration & 4.5 & - & 4.5 \\
\hline Share of Private Debt & $75 \%$ & $75 \%$ & $75 \%$ \\
\hline Share of Private Equity & $25 \%$ & $25 \%$ & $25 \%$ \\
\hline Share of Government Subordinated Debt & - & - & - \\
\hline Share of Government Equity & - & - & - \\
\hline Return on Private Debt & $8 \%$ & $8 \%$ & $8 \%$ \\
\hline Return on Private Equity & $18 \%$ & 0 & $18 \%$ \\
\hline Return on Government Subordinated & - & - & - \\
\hline Debt & & & \\
\hline Return on Government Equity & - & $\therefore$ & - \\
\hline Government Guarantee Payment & 0 & 5.5 & 0 \\
\hline
\end{tabular}

13. Table 4 illustrates a case where the government has limited control over the tollroad authority and the political pressures that may lower the toll to 2 . It is assumed that there is a 0.5 probability for the latter case. Now the guarantee has a 50 per cent chance of being called and therefore a cost. If the government wants to charge a fee for the guarantee, which equals its expected value then tolls have to be raised to 4.2 in the example. Consumers would thus pay for the risk imposed by the tollroad authority and political pressures in case the tolls remain as planned. Otherwise they would benefit from lower prices. Their expected price remains 3.1. Alternatively, the government could impose the cost on the taxpayer, for example, by not charging a guarantee fee. In that case consumers would expect to be better off when there is a chance of toll road authority reneging on its tariff commitments, while taxpayers would be worse off.

14. Moral Hazard and Adverse Selection. Risks such as that of reneging on tariff undertakings tend to arise from a lack of commitment on the part of the insured entity (one may call this "political risks", when those entities are in the public sector). Insuring against such misbehavior can create the temptation for the misbehaving party not to improve behavior but instead to sin even more (moral hazard). In other words, the existence of insurance will change the probability of reneging to more than 50 per cent. Full insurance against such risk will also tempt investors to seek out projects with excessive risk (adverse selection). Therefore, the insurance should not cover the risk fully, but leave beneficiaries somewhat exposed, like any "deductible" in insurance policies. 
TABLE 4: Government Guarantee not "Risk Free"

\begin{tabular}{|l|c|c|c|}
\hline & $\begin{array}{c}\text { Possible Outcome } \\
\text { (Probability = 0.5) }\end{array}$ & $\begin{array}{c}\text { Possible Outcome } \\
\text { (Probability = 0.5) }\end{array}$ & $\begin{array}{c}\text { Expected } \\
\text { Outcome }\end{array}$ \\
\hline Price & 4.2 & 2 & 3.1 \\
Quantity & 5 & 5 & 5 \\
Revenue & 21 & 10 & 15.5 \\
Current Costs & 5 & 5 & 5 \\
Cash Flow & 16 & 5 & 10.5 \\
Debt Service & 6 & 6 & 6 \\
Equity Remuneration & 4.5 & 4.5 & 4.5 \\
Share of Private Debt & $75 \%$ & $75 \%$ & $75 \%$ \\
Share of Private Equity & $25 \%$ & $25 \%$ & $25 \%$ \\
Share of Government Subordinated Debt & - & - & - \\
Share of Government Equity & - & - & - \\
Return on Private Debt & $8 \%$ & $8 \%$ & $8 \%$ \\
Return on Private Equity & $18 \%$ & $18 \%$ & $18 \%$ \\
Return on Government Subordinated & - & - & - \\
Debt & & - & - \\
Return on Government Equity & - & 5.5 & 2.75 \\
Government Guarantee Payment & 5.5 & - & 2.75 \\
Guarantee Fee & & & \\
\hline
\end{tabular}

15. The Nature of Political Risk. A small degree of political risk is normal and should be accepted by market participants. For example, under well-established regulatory regimes investors and consumers bear political risk as a matter of course. Regulators and governments anywhere have the unavoidable authority to adjust rules and regulations in ways that affect the property rights of players in the market. Often times, such powers to affect property rights and values are coupled with an obligation of the regulatory authority to see to it that the affected party receives just compensation or that its "equilibre financier" be maintained. However, in many cases, governments have the right and in deed the duty to change regulations in such a way that behavior of market participants is changed. That may require affecting their property rights - and thus their net worth, which is based on the expected stream of future cashflow - without full compensation.

16. More severe political risks will not be accepted by investors and are generally not insurable in private markets, because the guarantee is likely to be called and its existence may actually increase risk on account of moral hazard and adverse selection. While governments may be able to provide guarantees due to their taxation powers, it is only desirable to do so if the guarantee supports serious efforts to deal with the source of the risk. ${ }^{7}$

7 The same reasoning applies to straight government loans to projects and provides the case for conditionality under project loans. 
17. Separating Political from Commercial Risk. In practice, it is often difficult to write guarantees that neatly separate commercial from political risk. For example, the sovereign government may want to guarantee performance of a power company under the power purchasing agreement with a private power plant. Non-performance may take the form of non-payment due to inadequate final user tariffs, a form of policy risk. Alternatively, it may be due to mismanagement by the power company, a commercial risk. In both cases the credit-worthiness of the off-taker is in doubt and with it its ability to perform under the contract. The construction phase of a project may also be plagued by a mix of technical and policy risks, such as the risk of obtaining construction permits, environmental clearances, import licenses, rights-of-way, etc.

18. While perfect separation of political and commercial risk is difficult, there are clearly a number of risks such as (much of) construction risk as well as operating, price and demand risk including movements in exchange and interest rates that do not require taxpayer support. These risks can be split between investors and consumers depending on who is better able to manage, diversify, hedge or bear the risk in question. For example, if investors have access to the foreign exchange swap market they should probably bear the risk of foreign exchange movements. However, when there are no such hedges available, it may be legitimate to pass all sorts of price risks to consumers, for example, via tariff escalation clauses. If the resulting prices exceed consumers' willingness to pay, the project should not be undertaken, unless there is reason to subsidize it. Clearly, government need not insure risks, for which private markets provide coverage.

19. What risks may legitimately be guaranteed by the government is thus a matter of some debate and unavoidable judgment. It needs to reflect particular country and project situations. Generally accepted and relatively well defined is. insurance against war and insurrection, expropriation (including creeping expropriation) and impairment of currency transfer, a form of (partial) expropriation. ${ }^{8}$ Matters become fuzzier when performance of government or subsovereign entities in line with certain undertakings is concerned, for example, a power purchase agreement, a promise to provide complementary infrastructure (e.g. a road to a project), provision of permits for construction, import, operations, etc. It becomes more and more difficult to tell apart the proper exercise of discretion by some authority and improper interference. For some projects it may be inevitable that a guarantee cover some normal business risks alongside policy risks. But this may still be preferable to full credit guarantees.

Recommendation (3): Guarantees of "policy" risks should support a credible reform program but not substitute for it. In the medium-term policy reform should obviate the need for a guarantee. Beneficiaries of guarantees should bear a part of the risk, like a deductible. In structuring guarantees the government needs to take care that performance incentives for private investors are not undermined, essentially by not covering "normal business risk," including exchange rate and interest rate movements.

8 Private insurers provide coverage against these risks for limited time periods, maximum seven years and generally only for strongly collateralized transactions such as international trade credit and finance for mobile assets such as airplanes. Government-backed entities such as OPIC and MIGA provide coverage against such risks for longer periods. 
20. Case III: The Cost of Risk-bearing of Taxpayers is Lower than that of Investors. The third major reason for government support derives from the view that government has a lower cost of risk-bearing than the private sector, because it can spread risk in tiny amounts over many taxpayers (see Arrow and Lind, 1970). ${ }^{9}$ The problem is that it is never quite clear what the incidence on taxpayers is and, therefore, their cost of risk-bearing. The danger remains that taxpayers may be exploited, although there may be benefits from risk-sharing to the extent that taxpayers are more tolerant of risk than other investors (see Box 2). ${ }^{10}$

21. Tables 5 and 6 provide examples where government subordinated debt renders projects financible. In these cases we are back to the base case assuming that there is a 50 per cent chance each that traffic levels are at 5 or 2.5 vehicles respectively. The provision of subordinated debt can result in maintaining required returns to the private investors, while providing government with returns, which may well exceed the government borrowing rate. (Note that the cases in table 5 and 6 are constructed such that the required return for debt and equity are first provided for and the remaining cashflow goes to government for remuneration of its subordinated debt. In the examples, this is equivalent to assuming that private equity investors are limited to a maximum rate of return of 36 per cent - a simplification for expositional purposes, which simply illustrates the room for remuneration of subordinated debt.) Increases in the amount of subordinated debt can improve the expected rate of return on such debt, obviously until all finance is provided by government and the expected return is 10 per cent.

TABLE 5: Government Shares Risk by Subordinating Debt (1)

\begin{tabular}{|l|c|c|c|}
\hline & $\begin{array}{c}\text { Possible Outcome } \\
\text { (Probability - 0.5) }\end{array}$ & $\begin{array}{c}\text { Possible Outcome } \\
\text { (Probability = 0.5) }\end{array}$ & $\begin{array}{c}\text { Expected } \\
\text { Outcome }\end{array}$ \\
\hline Price & 4 & 4 & 4 \\
Quantity & 5 & 2.75 & 3.75 \\
Revenue & 20 & 10 & 15 \\
Current Costs & 5 & 5 & 5 \\
Cash Flow & 15 & 5 & 10 \\
Debt Service & 2 & 2 & 2 \\
Equity Remuneration & 9 & 0 & 4.5 \\
Share of Private Debt & $25 \%$ & $25 \%$ & $25 \%$ \\
Share of Private Equity & $25 \%$ & $25 \%$ & $25 \%$ \\
Share of Government Subordinated Debt & $50 \%$ & $50 \%$ & $50 \%$ \\
Share of Government Equity & - & - & - \\
Return on Private Debt & $8 \%$ & $8 \%$ & $8 \%$ \\
Return on Private Equity & $36 \%$ & 0 & $18 \%$ \\
Debt Service for Government & 4 & 3 & 3.5 \\
Subordinated Debt & & $6 \%$ & $7 \%$ \\
Return on Government Subordinated & $8 \%$ & & - \\
Debt & - & - & \\
Return on Government Equity & & & \\
\hline
\end{tabular}

9 Another reason for government support may be that the government is better informed about certain risks than private parties. But if it were, it could pass the information to the private sector rather than providing insurance.

10 While the rationale for this type of risk-sharing is weak, it de facto receives a lot of attention. 
22. Tables 7 and 8 provide examples where the government provides equity or debt pari passu with private debt or equity investors, and the returns of equity investors will be diluted. Such dilution may render projects unfinancible. However, to the extent that the required returns on private debt and equity fall as gearing ratios change this may not happen. The provision of pari passu finance can then render projects financible, however, only if the government accepts higher risks than the private sector for equal remuneration. Recall also the example of table 2, where an upfront subsidy was normally inferior to price subsidies. But when governments expect lower returns than private parties it could be that an upfront subsidy is justified.

23. In all cases, whether government finance is subordinated or not, it will render projects financible if and only if the government is willing to accept risk-adjusted returns that are below those of the private sector. As mentioned above, this can only be justified if one assumes that taxpayers do not require a risk premium for the risks they assume that is comparable to that required by private investors. While it is clear that taxpayers can to some extent be forced to accept low risk premia, it is less clear whether this is desirable.

TABLE 6: Government Share Risk by Subordinating Debt (2)

\begin{tabular}{|l|c|c|c|}
\hline & $\begin{array}{c}\text { Possible Outcome } \\
\text { (Probability = 0.5) }\end{array}$ & $\begin{array}{c}\text { Possible Outcome } \\
\text { (Probability }=0.5)\end{array}$ & $\begin{array}{c}\text { Expected } \\
\text { Outcome }\end{array}$ \\
\hline Price & 4 & 4 & 4 \\
Quantity & 5 & 2.5 & 3.75 \\
Revenue & 20 & 10 & 15 \\
Current Costs & 5 & 5 & 5 \\
Cash Flow & 15 & 5 & 10 \\
Private Debt Service & 0.8 & 0.8 & 0.8 \\
Private Equity Remuneration & 3.6 & 0 & 1.8 \\
Share of Private Debt & $10 \%$ & $10 \%$ & $10 \%$ \\
Share of Private Equity & $10 \%$ & $10 \%$ & $10 \%$ \\
Share of Government Subordinated Debt & $80 \%$ & $80 \%$ & $80 \%$ \\
Share of Government Equity & & & \\
Return on Private Debt & & & $8 \%$ \\
Return on Private Equity & $8 \%$ & $0 \%$ & $18 \%$ \\
Return on Government Subordinated & $36 \%$ & 1.2 & 7.4 \\
Debt & 10.6 & 5.25 & - \\
Return on Government Equity & 13.25 & - & \\
\hline
\end{tabular}


TABLE 7: Government Shares Risk Pari Passu in Debt

\begin{tabular}{|l|c|c|c|}
\hline & $\begin{array}{c}\text { Possible Outcome } \\
\text { (Probability }=0.5)\end{array}$ & $\begin{array}{c}\text { Possible Outcome } \\
\text { (Probability }=0.5)\end{array}$ & $\begin{array}{c}\text { Expected } \\
\text { Outcome }\end{array}$ \\
\hline Price & 4 & 4 & 4 \\
Quantity & 5 & 2.5 & 3.25 \\
Revenue & 20 & 10 & 15 \\
Current Costs & 5 & 5 & 5 \\
Cash Flow & 15 & 5 & 10 \\
Debt Service & 5 & 5 & 5 \\
Equity Remuneration & 10 & 0 & 5 \\
Share of Private Debt & 31.25 & 31.25 & 31.25 \\
Share of Private Equity & 37.5 & 37.5 & 37.5 \\
Share of Government Debt & 31.25 & 31.25 & 31.25 \\
Share of Government Equity & - & - & - \\
Return on Private Debt & $8 \%$ & $8 \%$ & $8 \%$ \\
Return on Private Equity & $26.7 \%$ & $0 \%$ & $13.35 \%$ \\
Return on Government Debt & $8 \%$ & $8 \%$ & $8 \%$ \\
Return on Government Equity & - & - & - \\
\hline
\end{tabular}

TABLE 8: Government Shares Risk Pari Passu in Equity

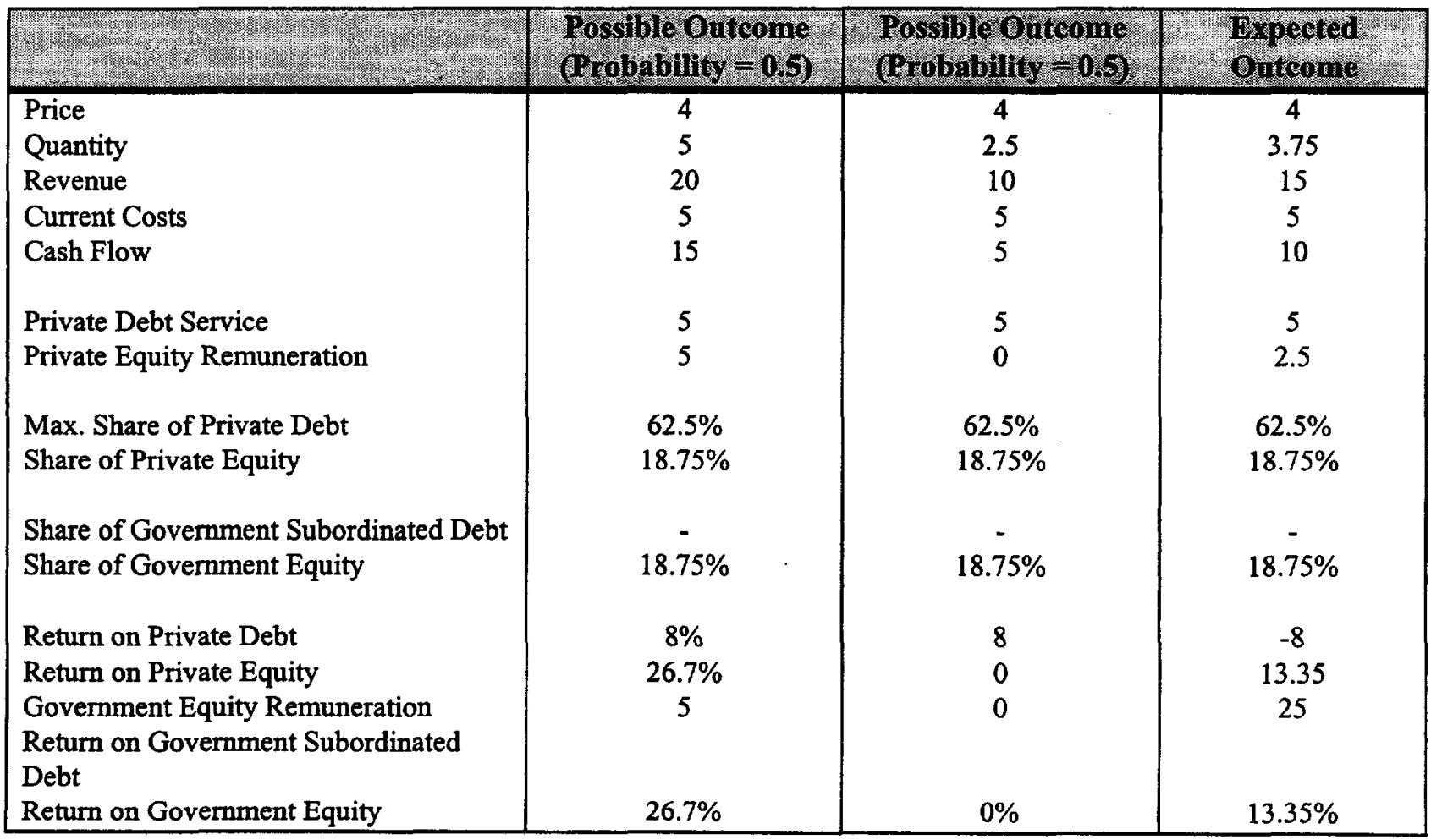




\section{Key Trade-Offs in Assessing Costs and Benefits of Government Support}

24. In general, the issue is to structure government support of project financing so as to:

- provide investors with a level of comfort needed to induce desirable investment;

- expose the taxpayer to the least possible risk (lowest risk-adjusted subsidy equivalent); and

- preserve incentives for private infrastructure providers to perform efficiently.

The trade-off between these considerations can only be quantified if one makes an explicit assumption about the risk premium (see Box 2) that taxpayers would require to assume the relevant project risks.

\section{Incentive Issues}

25. Risk-Sharing and the Power of Incentives. The potentially relatively low cost of riskbearing of taxpayers provides the basic theoretical rationale for government support through sharing non-political risks. To structure the best possible support, one would still need to consider how the various forms of support affect risk-sharing and, therefore, incentives, for example. ${ }^{11}$

- Cash subsidies that are dependent on project success provide very high-powered incentives for private investors to perform, because all variations in cashflow are borne by the project. However, cash subsidies that are unconditionally provided upfront weaken incentives to invest and operate efficiently. They are like "subordinated equity" without any right to an upside reward.

- With normal equity contributions government shares in future losses or gains. It thus makes investment by risk averse investors more likely, but by the same token lowers incentives to investors because the government shares some risks.

- With loans government shares downside risks without upside potential. Loans can be very effective in attracting equity investors into projects but they may also provide low-powered incentives to deal with the risks that are covered, because beneficiaries are protected from downside risk and thus tempted to misbehave (moral hazard) and pursue risky projects (adverse selection).

26. In principle, guarantees allow the government to achieve these goals in the best possible way by allocating risks to the parties that can best bear them. In other words, guarantees enable the government to provide conditional rather than only unconditional support. Depending on the project, the sector, the creditworthiness of the parties involved in a project and the track-record of the government itself, project support should ideally be structured differently.

27. Transaction Costs. Such flexibility also has costs. Non-standard forms of support, including non-standard guarantees may raise the costs of negotiation. Therefore, the ideal risksharing arrangement may not be worth defining and some simpler solution may be preferable. However, because governments may want to phase out guarantees for private investors over time,

\footnotetext{
${ }^{11}$ Government risk-sharing may, of course, also be achieved through adjustments of the tax system.
} 
they may not have the option to standardize guarantees much or run the risk of providing excessive guarantees.

28. Moral Hazard on the Government Side. Flexibility given to government officials may be abused. After all they decide on the use of tax money rather than their own. Therefore, the ideal risk-sharing arrangements may also not be desirable. For example, an equity contribution may be desirable in a project because it provides adequate risk-sharing. But because it is difficult to ascertain whether government as an equity investor is receiving adequate remuneration, it may be preferable to maintain government claims senior to equity, that is, at least in the form of subordinated debt, because then equity investors - if there are significant ones - are exposed prior to the taxpayer. If there is a risk that government subordinated debt may be underpriced and also abused, for example, because equity exposure is small, then senior straight debt may be preferable.

Recommendation (4): Government risk-sharing in normal business risks should only be considered as a last resort, if at all. To prevent excessive government exposure, decisions should be transparent and based on explicit cost-benefit analysis. Certain forms of support that severely expose the taxpayer, for example, equity investment by the government should either be prohibited or subject to various principles (for example, "buy no more than 25 per cent of the equity"; "require minimum capital at risk of 40 per cent of total assets"). Monetary limits should be placed on total government exposure. There should be an exit strategy for the government, wherever possible. 


\section{III}

\section{Managing Guarantees}

\section{Allocating Responsibility for Guarantee Decisions}

1. The Need for Discretion and Arms-Length Relationships. Guarantees have to be consciously structured so as to minimize government exposure and enhance policy reform. Judgment is unavoidable - both in regard to the detail of coverage to be provided and to the credibility of accompanying reforms. Therefore, those who decide on guarantees should be at arms-length from the authorities and investors that are promoting the project in question.

2. Consistency. To obtain consistency in the provision of guarantees and to develop judgment, it may be desirable to form a central guarantee authority. The measure of the guarantee authority's success must be total investment attracted relative to the amount of guarantees issued not the total value of guarantees issued. Of course, projects need to be of good quality and sound government liability management should be in place.

3. Attracting High Quality Staff and Learning. Countries such as Pakistan and the Philippines that have pursued several private infrastructure projects have come to see the value in establishing an agency which can learn and transfer lessons from one project to the next and across sectors - greatly reducing transaction costs in the process. Because the required expertise is often difficult to attract for civil servant salaries, it may be of interest to establish it as a somewhat autonomous agency outside the career civil service. Establishing such an agency allows concentration of expertise.

4. Guarantee Corporations. If the government envisages support for a large number of deals, it may be useful to establish a special corporation funded by the government. This makes it feasible to establish a visible limit on total government exposure by placing a ceiling on government financial exposure in the corporation via equity contributions or limits for the corporation's borrowing. The agency may be authorized to attract private equity and debt investors to help leverage the government's resources. It thus starts resembling a "government-sponsored enterprise" in the United States (Fannie Mae, Freddie Mac etc.).

Recommendation (5): Government should consider creating a central office, which is charged with structuring guarantees so as to minimize taxpayer exposure and to strengthen private performance incentives. Such an agency should be established at arms-length from project promoters both within and outside the government. Government should clearly circumscribe the types of guarantee coverages that such an agency may offer. If the government wanted 
to pursue a significant pipeline of private infrastructure projects it should seriously consider establishing a guarantee corporation, which would help develop standardized guarantee products, facilitate learning across projects, reduce the need for state and municipalities to issue guarantees, allow the employment of competent staff to do so and limit taxpayer exposure in a relatively transparent way.

\section{Valuation of Government Support Including Guarantees}

5. Regardless of which institution(s) manage(s) the government's support program for infrastructure, it will be important to establish valuation principles that allow government to understand and manage its exposure. Guarantees, in particular, tend to be difficult to value. Most countries do not show guarantees on their books and do not estimate their impact on the government's fiscal position. Only recently, starting with the United States 1991 Credit Reform Act have selected OECD countries started to assess the fiscal impact of guarantees. There are, however, a number of governments, which try to value the interest rate subsidy or default risk in some of their loans (Germany, Canada, Switzerland, New Zealand).

\section{BOX 1 - Government guarantees in OECD countries}

Government guarantee activities. Governments throughout the world tend to provide guarantees to private investors in a variety of activities. Prominent among such guarantees are deposit insurance for bank depositors as well as pension or social security insurance. Otherwise, guarantees for housing, agticulture, students, exports and public corporations tend to dominate the picture in OECD countries, while little is known about the broad pattern of guarantee exposure by developing countries. Even in OECD countries knowledge about guarantee exposure is sketchy. Existing data suggest that total guarantee exposure may amount to some $15-20$ per cent of GDP or more than a quarter of gross debt in OECD countries. This does, of course, not capture implicit guarantees, under which government may feel obliged to bail out failing firms or banks ("too big to fail") or to help uninsured citizens in need, for example, in the wake of natural disasters.

The cost of guarantee programs. While guarantee programs can provide very valuable support for private economic activity, in recent years some major countries have suffered large losses under some of their guarantee programs - deposit insurance and export credits. During the $1980 \mathrm{~s}$ OECD export credit agencies incurred losses equivalent to some 20 per cent on new business, while collecting on average premia of only 3 per cent. Most of the export credit losses have been on medium-and longer-term credit. This experience has prompted a slow change in guarantee management procedures. Most prominently, the United States has instituted more transparent accounting principles for its guarantee operations under the 1991 Credit Reform Act. The experience of export guarantee schemes is relevant for Governments which consider guaranteeing long-term infrastrueture investment as risks ate partly similar (medium to long term country risk) and in some ways more severe (risk of regulatory failure or creeping expropriation for firms with immobile investments, for example power plants).

6. The issue is simple. Full credit guarantees may expose the government to the same risks as loans. But they affect the cash position of the government differently. Firstly, guarantees produce cash inflows (guarantee fee) and only later, if the guarantee is called, expenses and with them an increase in the government's gross borrowing requirement. A loan bearing the same risks, first produces a cash outflow, which increases the government's gross borrowing requirement. Only later does the government obtain cash inflows from interest payments. Governments have 
thus been tempted to use guarantees rather than loans to reduce their gross borrowing requirement and to let their fiscal position appear better than it is. ${ }^{12}$

7. Valuation Principles. In principle, it is possible to calculate the cost of each form of government support. In the case of a direct subsidy, the total value of the subsidy is straightforward. When loans are priced below market it is also relatively easy - period by period to ascertain the subsidy element contained therein, although it may often be difficult to obtain a reasonable estimate for the market rate with which to compare the terms of the government loan.

8. It is similarly possible to estimate the subsidy element contained in the guarantee contained in a financial product like a loan or a straight guarantee. A loan which assumes full credit risk may be considered as composed of a risk-free loan minus a full credit guarantee ${ }^{13}$ (see Merton, 1992);

$$
\begin{aligned}
& \text { Risky loan }+ \text { loan guarantee }=\text { default-free loan } \\
& \text { or } \\
& \text { Risky loan = default-free loan - loan guarantee }
\end{aligned}
$$

9. The Credit Subsidy Equivalent. In principle, the value of a full credit guarantee can be calculated based on the difference between the interest rate of a risk-free loan and that of a normal market loan. If it is possible to obtain a reasonable value for a market rate, one can compare the fee charged for a guarantee with the difference in rates of guaranteed and non-guaranteed loans. ${ }^{14}$ To the extent that the guarantee fee is smaller than that difference, it contains a subsidy element. The subsidy elements contained in loans or guarantees may be called the credit subsidy equivalent. It can be decomposed into an interest rate subsidy and a default risk coverage.

10. Clearly, calculation of the credit subsidy equivalent becomes more complicated as government provides support, for which there is no market loan equivalent (e.g., loan or guarantee with maturities beyond those found in the market) or where return patterns are difficult to assess (e.g., equity contribution) or where the risks covered are not separately priced in the market, for example, most types of policy risk guarantees. In those cases, the principles of loan and guarantee valuation indicated above may, however, still allow the subsidy equivalent to be estimated within some range.

12 It is unlikely that governments can effectively fool their creditors for any length of time by resorting to off-balance sheet gimmicks. Creditors will know that the government is issuing guarantees even if there is no transparent accounting. The uncertainty about the government's financial position may actually induce creditors to require a higher risk premium. It could also be that creditors are not so worried about the government's guarantee exposure, because contrary to the case of loan exposure - the government has not yet parted with cash and might be tempted not to honor the guarantee if its financial position was weak i.e. it might prefer to default on guarantee commitments rather than on repayment commitments to creditors that directly lent to the government. In that case the value of the guarantee would be reduced. Governments may be able to fool their various creditors once, but will pay dearly for it later.

13 The formula assumes that the guarantor does not default. If such default were possible, the guarantor's default risk would need to be evaluated as well.

14 In those cases where there is an adequate history of the incidence of the risk covered by a guarantee it may be possible to use option theory to value the guarantee. Option theory clearly shows how the value of a guarantee increases dramatically with the volatility of the risk factor and with the maturity of the guarantee, because both factors make it more likely that the guarantee will be called (Mody and Patro, 1996). 
11. To obtain a measure of the subsidy equivalent that allows the size of subsidies contained in different forms of government support to be compared, one needs to discount the streams of subsidy payments of the different support instruments. If one uses the government borrowing rate as the discount rate one obtains a measure of the net budgetary impact of the subsidy equivalent. Suppose the government had a "subsidy corporation", for example, an importexport bank or an infrastructure support corporation, which were able to borrow at the government borrowing rate. If the subsidy equivalent measure were positive, the corporation would require an equivalent contribution from the budget to maintain the net worth of the corporation. If the measure were negative, the corporation could make payments, that is, dividends to the government (see Box 2).

\section{BOX 2 - The right discount rate for valuing guarantees}

The question remains whether the government should earn more than its borrowing rate plus a default premium on the support it provides to private players. Its borrowing rate only reflects the social costs of borrowing if taxpayers were voluntarily prepared to "invest" their tax payments in the expectation of no more than the government borrowing rate. However, the government borrowing rate may or may not reflect taxpayer's own valuation of risk. The government's borrowing rate would tend to be a lower bound for taxpayers' risk premium, because lenders to the government rely on its tax powers to repay credit. If one requires the government to earn a higher expected return on investments. then taxpayers should - like equity investors - be treated to dividends (tax rebates) from time to time. Also, the discount rate used to establish the subsidy equivalent should reflect this social cost of borrowing.

12. The credit subsidy equivalent provides a measure of the fiscal impact of a guarantee or a loan. The credit subsidy equivalent puts accounting for guarantees and loans on an accrual basis rather than the cash basis, which still governs most budget systems.

Recommendation (6): To enable government to manage its guarantee exposure it should consider valuing guarantees with their subsidy equivalent and assessing the fiscal impact on that basis, that is, by accrual rather than cash accounting.

\section{Managing Risk}

13. Valuation of the government's exposure needs to be complemented by means to actively manage the exposure so that it does not grow excessively or support the wrong projects. The following discussion is again concerned only with managing guarantee exposure. However, similar principles govern the management of other forms of financial exposure.

14. "Marking to Market". The credit subsidy equivalent provides the government with a measure to value a guarantee. The accuracy of this measure depends on how well future default and interest rate risk ${ }^{15}$ have been assessed. Such assessments are by nature imperfect and need to be revised from time to time. When an assessment shows that the subsidy equivalent has risen the

15 The subsidy equivalent will change when the government loan rate is fixed, while market rates adjust. 
government should either make an offsetting appropriation from the budget or it (or its guarantee corporation) may attach collateral that compensate it for the guarantee exposure.

15. Collateral. For example, the government may have guaranteed performance of a municipality (e.g. under a water purchase contract from a private water treatment plant), which receives tax revenues under the country's revenue-sharing system. In case the government's guarantee exposure rises, for example, due to a downgrading of the guaranteed agency by a rating agency, it may ask the beneficiary of the guarantee to pay an increased fee. Failing this it may attach money from the tax revenues that are due to the municipality. Such a system would be equivalent to the way brokers manage margin loans. ${ }^{16}$ In some countries similar systems exist, for example, Mexico and India. In Mexico, the infrastructure bank, BANOBRAS, issues guarantees which are backed by the tax revenues due to municipalities. However, BANOBRAS only attaches the tax revenues once the guarantee is called, not when the subsidy equivalent rises. Where an effective collateral system exists, the cost of the guarantee may be small. ${ }^{17}$

16. Wherever a government-guarantor can attach assets in case guarantee exposure rises or guarantees are called, the guarantee can be provided at low cost, because government is hedged. ${ }^{18}$ However, the case above assumes that government will not be obliged to make up the shortfall in tax revenues for the municipality in other ways - a strong assumption. When political pressures are likely to force the central government to bail out a company or municipality, it may be better not to provide guarantee in the first place, because it may simply postpone the day of reckoning and weaken discipline.

17. At the supranational level the World Bank guarantee is based on a similar principle (see Box 3). When a World Bank guarantee is called the Bank takes the money back from the government (taxpayers) which counterguarantees the Bank. As long as the World Bank's preferred creditor status remains effective, the cost to the Bank of providing the guarantee is low, that is, the same as extending a contingent loan. Other institutions, which lack the World Bank's preferred creditor status cannot provide a guarantee product at similarly low cost and have to charge much higher fees, if they are willing to take the risk at all.

18. Restrictions on the Use of Guarantees. Another way for the government to manage exposure is to restrict the uses to which guarantees may be put. As discussed earlier in this paper, it may limit the types of risks it is willing to cover and establish principles, which need to be followed (e.g., "provide guarantees only as part of a sensible reform package"). It may make an infrastructure project guarantee contingent on performance by the private operator. Other variations are possible too.

16 When the value of a portfolio of shares funded with margin loans drops, the broker marks the portfolio to market and asks the investor, who benefits from the margin loan (guaranteed by the broker) to increase her capital contribution. Otherwise, the broker has the right to possess some of the portfolio he holds as collateral and sell it to reestablish the required capital margin.

17 Just as the borrowing costs of margin lenders are minimal when portfolios can continuously be marked to market and seized as collateral, when value drops too much (see Merton and Bodie, 1992).

18 If the government-guarantor does not attach assets of the beneficiary it would attach money from the taxpayer to make the guarantee operation whole. 


\section{BOX 3}

While sovereign guarantees can cover subsovereign risks...

Guarantees by the sovereign government can deal with risks created by or associated with the behavior of subsovereign entities. For example, if a state-owned power company is not creditworthy, the government can guarantee its payment performance and render a power purchasing agreement between the power company and a private power plant financible. Alternatively, where investors are worried about their ability to convert local currency into foreign exchange and to transfer it abroad the government may help with a guarantee. Or where a municipality is the source of risk, the central government can insure. In all these cases, the value of insurance is grounded in the strength of the central government's financial position and its credibility, which sets the "sovereign ceiling".

.. entities with superior creditstanding are needed to deal with weak sovereign risks.

Where the sovereign itself is financially weak or suspected to be unreliable, its own word may not be enough to obtain finance or to obtain it at reasonable rates. In those cases, the sovereign may seek a guarantee from a supra-national entity such as the World Bank or a credit-worthy insurance agency such as the Overseas Political Risk Insurance Corporation (OPIC) of the United States, which enjoys good credit standing and is willing to provide the guarantee. Such a guarantee acts like a performance bond for the government. By taking out such a "performance bond or reinsurance" with a better credit risk, government may obtain access to finance at improved terms that more than offset the cost of "reinsurancet"

19. Fees. Finally, the government may charge a fee as compensation for the risk it takes and use them to build reserves against losses under its guarantee program. The fee may reflect market conditions for risks, which are similar to those insured by private insurers. However, in those cases the rationale for government guarantees may be questionable. For risks that no private insurer will cover there will be no easy way to establish a price. Risks are usually uninsurable in private markets when there is a great danger of moral hazard (e.g., policy risk of infrastructure projects). Therefore, the government will in any case wish to ask for some self-insurance by the beneficiary - similar to a deductible in insurance contracts - so as to reduce moral hazard. Furthermore a fee should be charged that covers the cost of administering the guarantee and that helps limiting the demand for guarantees from the private sector. However, care must be taken to avoid establishing the guarantee fee as "protection money" (the thief guaranteeing himself).

Recommendation (7): Government should establish a system to update the valuation of its guarantee exposure periodically together with mechanisms to adjust guarantee fees or to seize collateral in case fees are not paid as adjusted. In addition, the use to which guarantees can be put should be clearly limited and policies for appropriate guarantee fees and co-insurance requirements established. 
Alexander, I., "Regulatory Structure and Risk: An International Comparison," Mimeo, 1995.

Arrow, K.J. and R.C. Lind, "Uncertainty and the Evaluation of Public Investment Decisions," American Economic Review, 1970.

Blanchard, J.O., "The Vanishing Equity Premium", Finance and the International Economy 7, The Amex Bank Review, 1993.

Fabozzi, F. and P. Nevitt, "Project Financing," Euromoney, 6th edition, 1997.

Freshfields International Project Finance Group, "Project Finance," February 1995.

Kahn, E., "Risks in Independent Power Contracts: An Empirical Survey," The Electricity Journal, Vol. 4, no. 9, 1991.

Merton, C. Robert, and Z. Bodie, "A Framework for the Economic Analysis of Deposit Insurance and Other Guarantees," Working Paper No. 92-063, January 1992.

Mody, A. and D. Patro, "Methods of Loan Guarantee Valuation and Accounting," in World Bank Research Observer, February 1996.

Towe, M. Christopher, "The Budgetary Control and Fiscal Impact of Government Contingent Liabilities," IMF Staff Papers, Vol. 38 No. 1, March 1991. 

Policy Research Working Paper Series

Title

WPS1787 Trading Arrangements and
Industrial Development

WPS1788 An Economic Analysis of Woodfuel Management in the Sahel: The Case of Chad

WPS1789 Competition Law in Bulgaria After Centra! Planning

WPS1790 Interpreting the Coefficient of Schooling in the Human Capital Earnings Function

WPS1791 Toward Better Regulation of Private Pension Funds

WPS1792 Tradeoffs from Hedging: Oil Price Risk in Ecuador

WPS1793 Wage and Pension Pressure on the Polish Budget

WPS1794 Ownership Structure, Corporate Governance, and Corporate Performance: The Case of Chinese Stock Companies

WPS1795 What Educational Production Functions Really Show: A Positive Theory of Education Spending

WPS1796 Cents and Sociability: Household Income and Social Capital in Rural Tanzania

WPS1797 Formal and Informal Regulation of Industrial Pollution: Comparative Evidence from indonesia and the United States

WPS1798 Poor Areas, Or Only Poor People?

WPS1799 More for the Poor Is Less for the Poor: The Politics of Targeting

WPS1800 Single-Equation Estimation of the Equilibrium Real Exchange Rate
Author

Diego Puga

Anthony J. Venables

Kenneth M. Chomitz

Charles Griffiths

Bernard Hoekman

Simeon Djankov

Barry R. Chiswick

Hemant Shah

Sudhakar Satyanarayan

Alain de Crombrugghe

Xiaonian $\mathrm{Xu}$

Yan Wang

Lant Pritchett

Deon Filmer

Deepa Narayan

Lant Pritchett

Sheoli Pargal

Hemamala Hettige

Manjula Singh

David Wheeler

Martin Ravallion

Quentin Wodon

Jonath B. Gelbach

Lant H. Pritchett

John Baffes

Ibrahim A. Elbadawi

Stephen A. O'Connell
Date

June 1987

June 1997

June 1997

June 1997

June 1997

June 1997

July 1997

Contact

for paper

J. Ngaine 37947

A. Maranon 39074

J. Ngaine 37947

P. Singh

85631

N. Johl 38613

E. Somensatto 30128

M. Jandu 33103

J. Chinsen 34022

July 1997

S. Fallon 38009

July 1997

E. de Castro 89121

July 1997

P. Sader 33902

July 1997

S. Fallon 38009

August 1997

P. Kokila 33716 


\section{Policy Research Working Paper Series}

\begin{tabular}{|c|c|c|c|c|}
\hline & Title & Author & Date & $\begin{array}{l}\text { Contact } \\
\text { for paper }\end{array}$ \\
\hline WPS1801 & Regional Integration as Diplcmacy & $\begin{array}{l}\text { Maurice Schiff } \\
\text { L. Alan Winters }\end{array}$ & August 1997 & $\begin{array}{l}\text { J. Ngaine } \\
37947\end{array}$ \\
\hline WPS1802 & $\begin{array}{l}\text { Are There Synergies Between } \\
\text { World Bank Partial Credit } \\
\text { Guarantees and Private Lending? }\end{array}$ & Harry Huizinga & August 1997 & $\begin{array}{l}\text { P. Sintim-Aboagye } \\
38526\end{array}$ \\
\hline WPS1803 & $\begin{array}{l}\text { Fiscal Adjustments in Transition } \\
\text { Economies: Social Transfers and the } \\
\text { Efficiency of Public Spending: A } \\
\text { Comparison with OECD Countries }\end{array}$ & $\begin{array}{l}\text { Barbara Fakin } \\
\text { Alain de Crombrugghe }\end{array}$ & August 1997 & $\begin{array}{l}\text { M. Jandu } \\
33103\end{array}$ \\
\hline WPS1804 & $\begin{array}{l}\text { Financial Sector Adjustment Lending: } \\
\text { A Mid-Course Analysis }\end{array}$ & Robert J. Cull & August 1997 & $\begin{array}{l}\text { P. Sintim-Aboagye } \\
37644\end{array}$ \\
\hline WPS1805 & $\begin{array}{l}\text { Regional Economic Integration and } \\
\text { Agricultural Trade }\end{array}$ & Junichi Goto & August 1997 & $\begin{array}{l}\text { G. llogon } \\
33732\end{array}$ \\
\hline WPS1806 & $\begin{array}{l}\text { An International Statistical Survey } \\
\text { of Government Employment and } \\
\text { Wages }\end{array}$ & $\begin{array}{l}\text { Salvatore Schiavo-Campo } \\
\text { Giulio de Tommaso } \\
\text { Amitabah Mukherjee }\end{array}$ & August 1997 & $\begin{array}{l}\text { M. Gueverra } \\
32959\end{array}$ \\
\hline WPS1807 & $\begin{array}{l}\text { The Ghosts of Financing Gap: } \\
\text { How the Harrod-Domar Growth } \\
\text { Model Still Haunts Development } \\
\text { Economics }\end{array}$ & William Easterly & August 1997 & $\begin{array}{l}\text { K. Labrie } \\
31001\end{array}$ \\
\hline WPS1808 & $\begin{array}{l}\text { Economic Transition and the } \\
\text { Distributions of Income and Wealth }\end{array}$ & Francisco H. G. Ferreira & August 1997 & $\begin{array}{l}\text { M. Geller } \\
31393\end{array}$ \\
\hline WPS1809 & $\begin{array}{l}\text { Institutions in Transition: Reliability } \\
\text { of Rules and Economic Performance } \\
\text { in Former Socialist Countries }\end{array}$ & $\begin{array}{l}\text { Aymo Brunetti } \\
\text { Gregory Kisunko } \\
\text { Beatrice Weder }\end{array}$ & August 1997 & $\begin{array}{l}\text { M. Geller } \\
31393\end{array}$ \\
\hline WPS1810 & $\begin{array}{l}\text { Inspections and Emissions in India: } \\
\text { Puzzling Survey Evidence about }\end{array}$ & $\begin{array}{l}\text { Sheoli Pargal } \\
\text { Muthukumara Mani } \\
\text { Mainul Huq }\end{array}$ & August 1997 & $\begin{array}{l}\text { E. Krapf } \\
80513\end{array}$ \\
\hline WPS1811 & $\begin{array}{l}\text { Agricultural Development: Issues, } \\
\text { Evidence, and Consequences }\end{array}$ & $\begin{array}{l}\text { Yair Mundlak } \\
\text { Donald F. Larson } \\
\text { Al Crego }\end{array}$ & August 1997 & $\begin{array}{l}\text { P. Kokila } \\
33716\end{array}$ \\
\hline
\end{tabular}

